Yehudit Ronen

\title{
Religions at War, Religions at Peace: The Case of Sudan
}

\author{
»Allah wept when he created the Sudan«.
}

»Sudan entered the twenty-first century mired in not one but many civil wars, « rightly noted one scholar, who had held a first-hand research on the state and its society. ${ }^{2}$ Indeed, what had been seen in the mid-1950s and with increased vigor during the 1960s-1980s as a war between Sudan's two starkly-different human blocs - the Arab Muslim majority living in the north of the country, and the African, Christian and animist minority concentrated in the south - has largely expanded beyond these geopolitical, ethnic and religious bounds throughout the 1990s and early 2000s.

In fact, the longer the war has lasted, the greater it expanded both in scope and essence, assuming the pattern of interlocking civil wars while engulfing major areas of the vast Sudanese landscape. Moreover, the more the war extended the deeper it has encroached beyond the country's borders, being transformed from an intrastate dispute to an interstate one and vice versa. This, in turn, has enormously strengthened the pressure and threat upon Sudan's territorial integrity, political and economic stability, human well-being and foreign relations, and, in fact, upon every facet of the state's life, dragging it into a frightful maelstrom of havoc.

It was of no surprise, therefore, that the northern society and the southern society, which for methodological convenience alone and notwithstanding the broadly complex potential for inaccuracy, will henceforth be referred to as "north « and »south, «breathed a particularly deep sigh of relief at the signing of the set of interim "peace agreements « in mid-2004. These projected hope for an imminent end to the protracted armed conflict. Yet, and not accidentally, just as the south-north conflict has been paving its tormenting way to resolution, or at least toward a considerable lull in the fighting, another war has been vigorously ravaging the western region of Dafur, dizzying the state and its people in a new cycle of chaos and human tragedy. Concurrently, other grievances, in the Nuba Mountains, the Blue Nile and the Red Sea area, have continued to simmer, fueling the fire of belligerence across the vast Sudanese territory.

One of Sudan's political figures had once figuratively compared the war-torn state to » a powerful eagle, yet suffering a broken wing, « pointing out that without he-

1 An Arab proverb, quoted by Edgar O'Ballance, The Secret War in the Sudan: 19551972, Hamden, Connecticut: Archon Books, 1977, p. 32.

2 Douglas H. Johnson, The Root Causes of Sudan's Civil Wars, Bloomington: Indiana University Press, 2003, preface, p. xiii. 
aling its wound the eagle will never fly again, in which case its fate will be doomed. ${ }^{3}$ The still dangerously persevering north-south conflict, although largely muffled in summer 2004, joined by all other local violent inflammabilities, have considerably increased the concern for the eagle's life.

This article focuses on Sudan's dominant north-south armed conflict, surveying its full continuum in the years 1955-2004. The study focuses its analysis on the role and impact of religion in shaping the conflict's course and effects during both times of war and of peace. More explicitly, the article examines to what extent this conflict has been religious in its character, or rather, whether religion was merely one of the factors, albeit a powerful one, in fueling the flames of war. While discussing this challenging topic, particularly as interfaith tensions have always been tightly and almost inseparably interwoven into the most intricate Sudanese fabric of life, the paper also sheds light on, and maps relevant pre-independence historical junctions, as well as central political, economic and foreign policy crossroads of Sudan during the era of independence.

\section{Background to the Conflict: The Fertile Soil for Sprouting Violence}

The origins of Sudan's civil war are deeply rooted in the $19^{\text {th }}$ century. At the beginning of the 1820s, the army of Muhammad 'Ali, the Ottoman-Egyptian Viceroy, occupied the Arab-Muslim northern region of what later became known as the Sudan. Penetrating the south of this area, his forces enslaved many of its African animist peoples, dwindled their economic resources and drained their means of subsistence. $\mathrm{Mu}$ hammad 'Ali was assisted in these incursions by armed Arab Muslims from northern Sudan, who cruelly suppressed the southerners and were, therefore, positioned in their collective consciousness as responsible for their calamity. This was the first large-scale, bitter encounter between people from the Muslim Arab north and the non-Muslim and non-Arab south of Sudan, setting up the foundations for further enmity. ${ }^{4}$

The last two decades of the $19^{\text {th }}$ century brought about the Mahdi pronounced Islamic uprising, which established the Mahdist »state in the Sudan. The Mahdists acted militantly to Islamize the people in the Sudanese realm and thus further sharpened the south's animosity toward the Arab Muslim north. ${ }^{5}$

3 Africa Contemporary Record 1977-1978, New York: Africana Publishing Corporation, 1979, Vol. X, p. B121, quoting Buth Diu, one of the veteran Southern politicians.

4 For the Ottoman-Egyptian period in the Sudan, see e.g., Richard Gray, A History of the Southern Sudan, London: Oxford University Press, 1961; 'Abd al-Rahman Al-Raf'i, Misr wal-Sudan, Al-Qahira: Dar al-Qawmiyya Liltaba'a wal-Nashr, 1966; Hasan Ahmed Ibrahim, »The Resistance of Southern Sudanese People During the first Imperialist Era, "The Role of Southern Sudanese People in the Building of Modern Sudan, Juba [Southern Sudan]: University of Juba 1986.

5 For the Mahdist period, see e.g., Robert Collins, The Southern Sudan, 1883-1898, New Haven and London: Yale University Press, 1962; P. M. Holt, The Mabdist State in the Sudan, 1881-1898, Oxford: Clarendon Press, 1970; and Dunstan M. Wai, The AfricanArab Conflict in the Sudan, New York: Americana Publishing Company, 1981. 
The liquidation of the Mahdist rule in 1898 following aggressive British-Egyptian military pressures was immediately followed by the latter's condominium rule over Sudan (with Egypt being merely a formal partner). It was throughout this colonial period that Christianity and the English language were increasingly spread across the African animist south of Sudan, projecting, thereby, new significant variances and potential rancor between the two regions societies.

Moreover, considering the whole of Sudan as highly important for their strategic and political interests, primarily for maintaining the control of the Nile Basin and the Suez Canal in neighboring Britain-controlled Egypt, the colonial British rule treated the northern and the southern societies differently, thereby further widening the gaps between them. The colonial rule even implied an effective separation policy between the south and the north. It was only in the late 1940s that Britain canceled this policy and referred to Sudan as a single territorial and administrative entity, yet without actually incorporating the south in the unification process, nor in Sudan's political, administrative and economic advance towards independence. In stark contrast, however, the colonial rule closely collaborated with the Arab-Muslim elite in the north, training it to assume the reins of leadership in the post-colonial period. ${ }^{6}$

This British attitude, actively fostered by the majority Arab Muslim elite in Khartoum, was perceived by the minority society in the south as deliberate discrimination, suiting the north's self-imposed politico-religious and economic dominance over the Sudanese national identity. ${ }^{7}$

Also significant in inflaming north-south tensions was the arbitrary demarcation of Sudan's international boundaries by the colonial rule in complete disregard of local religious and ethnic affiliations and thus incorporating largely diversified ethnic and religious populations within one Sudanese territory. Being located thus at the crossroads of the Arab Middle East and sub-Saharan Africa, Sudan has constituted a microcosm of both the Arab world and the African continent in terms of religions, races, cultures, languages, as well as other basic characteristics.

Given all these historic circumstances and pluralistically diverse geographic and human features, the Sudanese experience can clearly be defined as one of »fluidity of identity $\ll^{8}$ and of $»$ multiple marginality «, being on the fringe of many cultural and political zones, but central to none. ${ }^{9}$

6 For the British rule, the south and the north-south relations on the eve of independence, see e.g., Muddathir 'Abdel Rahim, Imperialism E Nationalism in the Sudan, Khartoum: Khartoum University Press, 1969; Oliver Albino, The Sudan: A Southern Viewpoint, London: Oxford University Press, 1970; Robert O. Collins, Land Beyond the Rivers, New Haven and London: Yale University Press, 1971; Francis M. Deng and Robert O. Collins, The British in the Sudan, 1898-1956, Stanford, Ca: Hoover Institution Press, 1984.

7 Bona Malwal, People E Power in Sudan, London: Ithaca Press, 1981; Joseph Lagu, The Anya-Nya Struggle: Background and Objectives, January 1972.

8 John Obert Voll and Sarah Potts Voll, The Sudan Unity and Diversity in a Multicultural State, Boulder, Co: Westview, 1985, p. 7.

9 Ali A. Mazrui, »The Multiple Marginality of the Sudan, "Sudan in Africa, Yusuf Fadl Hasan ed., Khartoum: Khartoum University Press, 1971, pp. 2, 240-255. 
Against this backdrop it is no wonder that the conditions in Sudan have been a fertile soil for the sprouting of the seeds of discord. On August 18 $8^{\text {th }} 1955$, just on the verge of independence and largely because of that specific timing, the south's political and economic grievances and even fears of the north's taking control over it, manifested themselves in an armed mutiny of southern soldiers serving in the Britishestablished Equatoria Corps. The intention to station them in the north, concurrent with an intention to position northern troops at strategic points in the south, nourished by a cumulatively strong distress in other aspects and reinforced by an industry of hostile rumours, ignited the rebelliousness. Although the uprising was promptly suppressed by the British, a hard core of southern troops escaped to reorganize later as a guerrilla army, calling itself »Anya-Nya«, literally meaning a snake venom..$^{10}$ From that juncture of affairs onwards, the southern rebels became the state's nightmarish "slant serpent, « stinging the north and poisoning it, while paradoxically intoxicating itself as well.

\section{The Role of Religion in the First Round of War: 1955-72}

Perceiving itself as the sole legitimate ruler of the state since independence on January $1^{\text {st }} 1956$, the Arab-Muslim leadership in the north hegemonously engaged itself in shaping Sudan's political, religious and cultural identity in accordance with its own image, ignoring the south's different, and sometimes contradicting, interests and sensitivities. Moreover, the northern ruling elite increasingly imposed Arabization and Islamization on the south, striving to achieve national unity through uniformity. This determination was flagrantly illustrated among others at that stage by the call of the Grand Qadi of Sudan, Hasan Muddathir, for the immediate adoption of an Islamic constitution. ${ }^{11}$

Clearly, this monocentricly patronizing approach, which certainly included other essential ingredients than religions, further inflamed the enmity of the large minority society in the south, numbering in early 1956 c. 3 million out of the total Sudanese population of c. 10 million and inhabiting a third of the 2.5 million square kilometers of the Sudanese territory. ${ }^{12}$

10 For details on the rebelliousness, the subsequent rise of southern nationalism and the crystallization of the southern Anya-Nya guerilla army, see e.g., Report of the Commission of Inquiry into the Disturbances in the Southern Sudan, 1955, McCorquedale and Co. (Sudan, 1956), an official British document; O’Ballance, pp. 32-67; K.D.D. Henderson, Sudan Republic, London: Ernest Benn, 1965, pp. 172-77; Elias Nyamlell Wakoson, »The Origin and Development on the Anya-Nya Movement, 1955-1972«, Southern Sudan: Regionalism E Religion, Mohamed Omer Beshir ed., Khartoum: University of Khartoum, Graduate Colleague Publications, 1984, pp. 127-204.

11 Francis Mading Deng, »War of Visions for the Nation, «Sudan: State and Society in Crisis, John O. Voll, ed., Bloomington and Indianapolis: Indiana University Press, 1991, p. 25 , and note no. 1 , p. 39.

12 Albino, pp. 3-4 and M.O. Beshir, The Southern Sudan Background to Conflict, Khartoum: Khartoum University Press, 1970, p. 5. By the end of 2002, the IMF reckoned 
During the 1960s, fighting between north and south deteriorated to a full-blown civil war. The Government in the north, however, systematically belittled the severity of the war..$^{13}$ Having turned a deaf ear to the south's growing belligerence, nourished by its demand to change the state's agenda on a wide-range of issues, one of them being the state's recognition of the different ethnic-religious character of the south, clearly mirrored the north's egocentricity, as well as self-confidence in crushing the rebelliousness. This, in turn, further reinforced the south's fighting spirit. Meanwhile, as the war escalated, both conflicting sides increased their political and military reliance upon foreign props, thus spilling the conflict over the national boundaries to both the regional and international vicinities.

Concurrently at that juncture of bitter fighting routine at the turn of the 1960s1970s, Sudan's domestic, regional and international arenas underwent coincidingly dramatic substantial changes, which drastically affected the conflict's course. ${ }^{14}$ Topping these changes was the ascent to power in Sudan of Ja'far Muhammad al-Numayri in a military coup on May $25^{\text {th }}$ 1969. In contrast to previous Sudanese governments, the Numayri military regime appeared determined from its very inception to bring about a political resolution to the armed dispute.

Most significant regionally, in neighboring Uganda Idi Amin Dada took power in January 1971. Due to his dramatic ideological and political rapprochement towards the Arab world, including the Sudanese Arab government (mainly under the pressure of Libya), he closed the Ugandan major route of foreign military supplies to the fighting south, thus seriously eroding its military might.

Internationally, Numayri's desertion of Sudan's pro-Soviet orientation in favor of the West in the wake of the Moscow-backed failed attempt to topple his regime on July $19^{\text {th }} 1971$, also helped to reinforce the prospects for ending the war. From that juncture onwards, maintaining Numayri in power became a vital interest of the West, supporting him politically and financially, while goading him to reach a resolution to the armed conflict.

Also of great importance was the maturation of awareness of both Sudanese warring parties and particularly significant of the much more powerful north, ${ }^{15}$ of their inability to win on the battlefield and of their unwillingness to keep paying the terribly high prices of bloodshed and devastation. Seemingly, both sides reached the stage of conflict resolution, referred to by various scholars as the stage of »conflict ripeness. $\ll^{16}$

that the Sudanese population had reached 32.9 m., about $60 \%$ Muslims. See Sudan: Country Profile, London: The Economic Intelligence Unit, 2004, pp. 27-28. One should bear in mind that holding a comprehensively reliable census throughout the war-torn Sudanese territory in the early 2000s was a nearly impossible mission.

13 Prime Minister Ahmed Mahgoub, quoted in O'Ballance, p. 79.

14 For aspects related to Sudan's war and its regional and international extensions, see e.g., Peter Anyang' Nyong'o, »Crises and Conflict in the Upper Nile Valley, « and Stephen John Steadman, »Conflict and Conflict Resolution in Africa: A Conceptual Framework, "Conflict Resolution in Africa, Francis M. Deng, I. William Zartman eds., Washington D.C.: The Brookings Institution, 1991, pp. 95-114, and pp. 377-83.

15 O'Ballance, p. 115, quoting President Numayri's statement from 1 August 1969.

16 E.g., Richard N. Haas, »Ripeness and Settlement of International Disputes, "Survival, Vol. 30, No. 3, 1988, pp. 232-51. 


\section{Religion at Peace Time: $1972-83$}

On February $27^{\text {th }} 1972$, after a period of short, yet intensive, mediation, mainly brokered by external actors led by US-backed Ethiopia and the World Council of Churches, the conflicting sides reached a compromise embodied in the Addis Ababa Peace Agreement. This endowed the south with a Regional Self-Government within a unified state, while perpetuating the North's dominant control over the state's foci of power and national resources. ${ }^{17}$

Among others, the Peace Agreement formally anchored the south's religious freedom, while stipulating that »every person should enjoy freedom of religion ... and the right to profess it publicly and privately. ${ }^{18}$ In fact, it was the first time since the inception of the dominantly-Islamic Sudanese state that Islam, Christianity and African traditional religions were acknowledged, at least formally, as being of equal legitimacy.

Considerably relieved, the south perceived this settlement of religious freedom as predicting good chances of success for other fields of coexistence, most essentially the political and economic spheres. Interestingly, the religious issue, which was not dominant on the north-south agenda during the war, assumed at the just-born, fragile peace phase, a much more prominent role in shaping the post-war relations, serving - mainly for the south - as a litmus test for examining the confidence-building process. Moreover, for the ethnically, culturally and politically segmented southern society, its nonMuslim characteristic became a major source of identification and cohesion.

Not surprising against this background, growing inter-religious suspicion over the role of religion in the state's life remarkably raised between north and south in mid1973. Most apprehensive in the south's eyes was the demand of militantly Islamic circles in Khartoum's government, which have always been considered by the south as explicit religious-political strongholds of the Arab Muslim north, that Islam be the official religion of Sudan, including the south. This demand, undermining the principle of religious freedom as guaranteed by the Peace Agreement, was considered in the south as a strong blow to its religious status and as a bad omen for its relations with the north in other areas of common interest. The south's alarm increased not only because the issue was raised only a short time after the end of the war, with its tragedies still fresh in mind, but also because it was voiced during the debate over the country's draft constitution and not merely by a marginal political or religious group.

Most vociferous among the militant Islamic circles in the north were the Muslim Brothers. While they had been intentionally excluded by Numayri's northern-based government during the conflict resolution process, the Muslim Brothers returned to

17 For details on the 1972 conflict resolution, see e.g., Hizkias Assefa, Mediation of Civil Wars: Approaches and Strategies, The Sudan Conflict, Boulder, Co: Westview Press, 1987; Donald Rotchild and Caroline Hertzell, »The Peace Process in the Sudan, 19711972, «topping the Killing: How Civil Wars End, Roy Licklider ed., New York: New York University Press, 1993.

18 For the full text of the agreement and related aspects, see Arab Report and Record, London, March 1972, Supplement, pp. 161-69 and Abel Alier, Southern Sudan: Too Many Agreements Dishonored, Exeter: Ithaca Press, 1990, pp. 41-104. 
the center of politics towards the mid-1970s and assertively propagated to »repair « what they perceived to be an unforgivable damage to the once superior position of Islam in Sudan. They forcefully insisted that all legislation in the state must be based on, or be in conformity with, Islamic jurisprudence.

The crisis over the draft constitution finally abated, apparently as the result of the political zigzagging in Numayri's position toward the Muslim Brothers to their clear detriment. Yet inter-religious tensions continued to loom heavily over the $\mathrm{Su}-$ danese political mist. Moreover, in the first years of the 1980s, these tensions accumulated much greater weight, becoming, in fact, a prominent bone of contention between the north and south. Interestingly, these tensions eclipsed, to a large extent, other sources of crisis of much greater implications to both sides $<$ immediate and cumulative socioeconomic and political relief.

In fact, the erosion in the north's sensitivity viz-a-viz the religious - as well as economic and political - position of the south was mainly a by-effect, albeit of great importance, of the "national reconciliation « process. This was launched by Numayri since 1977 with the deeply Islamic-oriented opposition, which had attempted to overthrow him, mainly with the collaboration of hostile Libya, in July 1976. Within this context of reconciliation, the still potentially dangerous opposition leaders returned from exile in Libya and Ethiopia and were engaged in integration attempts into Khartoum's political system. Most successful among them was Dr. Hasan 'Abdallah al-Turabi, the militant and tough head of the Islamic Charter front - a split of the Muslim Brothers, who met the challenge. ${ }^{19}$

Eager to see Turabi as a part and parcel of the country's political establishment and thus not only demotivating him to topple the regime but also relying upon him versus other hostile opposition forces, Numayri soon took up a series of moves to placate the Islamic leader. Prominent among them was the establishment of a state committee, composed of purely northern Muslims including Turabi himself, entrusted with the examination of the adjustment of the state laws to the Shari'a, the Holy Islamic Law. Thus, the president signaled not only his political interest but also his sympathy to the strengthening of the state's Islamic character, notwithstanding its adverse effect on the relations with the south. A short while later, Numayri even went a step further, appointing Turabi to various senior executive posts, thus providing him with greater influential political and religious levers. ${ }^{20}$

19 For the »National Reconciliation « Process, see Mohammed Beshir Hamid, The Politics of National Reconciliation in the Sudan: The Numayri Regime and the National Front Opposition, Washington D.C.: Georgetown University, 1984.

20 For the prominence of the Muslim Brothers in Sudan's politics throughout the late 1970s- the 1980s, see Hasan Makky Muhammad Ahmed, Harakat al-Ikbwan al-Muslimin fi al-Sudan, 1944-1969, Kuwait: Dar al-Qalam lil-Nashr, 1986; Hasan al-Turabi, alHaraka al-Islamiyya fi al-Sudan: al-Tatawar wal-Kasb wal-Manhaj, al-Khartoum: place of publication not written, 1989; Ibrahim Riad, "Factors Contributing to the Political Ascendancy of the Muslim Brethren in Sudan, "Arab Studies Quarterly, Vol. 12, No. 3 and 4, Summer/Fall 1990 and Abdelwahab El-Affendi, Turabi's Revolution: Islam and Power in Sudan, London: Grey Seal, 1991. 
These moves coincided with increasing calls by the traditionally powerful politico-religious forces in the north, the Umma Party and the Unionist Democratic Party, which had chosen to remain outside the "national reconciliation « framework, yet yielded a powerful position in domestic politics, to turn the Koran into the decisive source of legislation and to reevaluate the peace agreement so as to further enhance the position of Islam. ${ }^{21}$

The seriously distressed south, while embittered by growing socioeconomic and political disappointments and further hardships more than anything else, channeled its anxiety largely to the religious sphere. This was clearly echoed in massive protest demonstrations against the north, calling Numayri to adhere to the principle of »religion to the individual, the state for all. $\ll^{22}$ Notwithstanding, Numayri's disregard for the rights and needs of the south (as well as the north) grew steadily. Tragically for the whole state, the Sudanese president shifted emphases from the country's management to Islamic practices toward the mid-1980s. Being apparently affected by his severely deteriorating health and political fatigue, the president was encircled by his Islamic Sufi entourage rather than by political and economic advisory teams. ${ }^{23}$ This injected into the already badly eroded north-south relations new doses of insolence.

Seriously worried and politically assertive than ever before, southern circles increased their pressure upon the north to fully comply with the peace agreement and supply the south with its fair share of the economic and political »national pie « and to officially honor the south's non-Muslim character. Numayri, however, politically incompetent, ignored the south's growing ferment, as he did viz-a-viz various segments of populations in the north, concentrating his drained political attention on securing his immediate position in power and on glorifying the position of Islam across the country.

The president's failing functioning was alarmingly mirrored by his arbitrary »national unity policy « during 1982-83, acting to integrate the non-Muslim and non-Arab south into the power holds of the state. This policy, starkly contrasting the peace agreement, peaked in Numayri's division of the south into three regions in June 1983, thus eroding its political power versus the north, while securing the latter's control over the oil resources discovered in south Sudan at the beginning of the 1980s. The south's distrust and fury heightened further, perceiving the oil as its own asset and viewing it, precisely as did the Khartoum government, as a one-time opportunity to extricate itself from the economic and political abyss. Thus, paradoxically, the newly discovered oil significantly exacerbated the internal feud, having, in any case, a much greater impact on its escalation than that of the intra-religious confrontation.

Accidentally or not, while Numayri was staying abroad for one of his many medical treatments in early 1983, having no idea of what was going on even in the political arena in the north, the south's tiding frustration erupted in an armed insurgence, mar-

21 Arabia and the Gulf, London, April 10th 1978, p. 9.

22 Bona Malwal, a senior southern politician, Sudanow, Khartoum, October 1977, and Africa, London, April 1978.

23 Numayri even published two books on Islam, titled Al-Nahj al-Islami Limadha?, Cairo: al-Maktab al-Misri al-Hadith, 1980 and al-Nahj al-Islami Kayfa?, Cairo: alMaktab al-Misr al-Hadith, 1985. 
king the return of Sudan into the cycle of war. Totally incompetent, Numayri clinged to his religious preoccupation, further fueling the fighting by implementing the Shari' Islamic law as the core of a new legal system in Sudan in September 1983. This move imprinted the final stamp on the south's long-feared Islamization of the country, violating constitutional provisions for the non-discrimination of the pluralistically-religious Sudanese society. ${ }^{24}$

While the imposition of the Shari'a was widely, yet wrongly, assumed to have played the dominant role in rekindling the north-south armed conflict, one should bear in mind that the armed rebelliousness had erupted again already early in 1983 and gathered a steady momentum in the spring and summer of that year, in fact quite ahead of the imposition of the Shari'a law.

United in its anti-Shari a position, notwithstanding Numayri's sporadic and somewhat vague statements on the exclusion of the non-Muslim south from the Shari'a's penalty practices, such as amputations and floggings, the south's spirit of fighting was strengthened. Clearly, vociferous voices from the influential Islamist hard-liner Turabi, insisting on enforcing the Shari' $a$ »on all the Sudanese public, even on the non-Muslim minorities, with no exception, $\ll^{25}$ intertwined by the carrying out of public amputations not only in Khartoum - the stronghold of the Muslim north - but also in the Muslim but non-Arab Nuba Mountains, Darfur and other regions across Sudan, largely reinforced the south's bellicosity.

Soon, a new southern guerilla organization, calling itself »the Sudan People's Liberation Army « (SPLA) - the military wing of the Sudan People's Liberation Movement (SPLM), dominated the renewed armed conflict, dictating to a large extent its pace and essence. Most prominently, the southern SPLA under the command of Col. John Garang de Mabior increasingly spearheaded the fighting against government-operated oil installations, focusing, thereby, its armed struggle over the oil resources, which both the conflicting sides perceived as the only ray of hope for their welfare and even survival. ${ }^{26}$

Already in the mid-1980s, the determined southern SPLA moved far beyond religious, political and economic demands pertaining to the south itself, being now committed to overthrow the Numayri regime and create a new comprehensive order in Sudan. ${ }^{27}$

24 For the imposition of the Shari'a, see e.g., Scott H. Jacobs, »The Sudan's Islamization, « Current History, May 1985, pp. 205-32; John L. Esposito, »Sudan's Islamic Experiment, «The Muslim World, Vol. 76, Nos. 3-4, 1986; and John O. Voll, »Revivalism and Social Transformation in Islamic History, « both papers in Carolyn Fluehr-Lobban, »Islamization in Sudan: A Critical Assessment, «The Middle East Journal, Vol. 44, No. 4, 1990, pp. 610-23, and Ann Mosley Lesch, The Sudan-Contested National Identities, Bloomington and Indianapolis: Indiana University Press, 1998, pp. 54-58.

25 In a statement to Al-Sahafa, Khartoum, 2 October 1983.

26 For the role of oil in exacerbatin the north-south antagonism, see Salua Kamil Dallalah, "Oil and Politics in Souther Sudan, "North-South Relations in the Sudan Since the Addis Ababa, Mom K. N. Arou \& Yongo-Burre B. eds., Khartoum: University of Khartoum Press, 1988, pp. 430-55 and God, Oil and Country: Changing the Logic of War in Sudan, Brussels: International Crisis Group Press, 2002.

27 R. SPLA, the clandestine radio of the southern rebels, established on 18 October 1984 and transmitted from hostile Ethiopia, 22 March 1985 (Daily Report [DR]: Near East 
Indeed, it was not long before the south's flames of war liked off Khartoum, playing a significant role in the ousting of the regime in a military coup on April $6^{\text {th }} 1985$.

\section{Religion at War Time: 1983-2002}

The sharp controversy over the place of the Shari' $a$ law in the multi-religious and widely diversified Sudanese society forcefully lingered further into the state's politics and the north-south conflict during the second half of the 1980s. This was plainly discernable as the Transitional Military Government of 'Abd al-Rahman Siwar al-Dahab, which headed Sudan's "Revolution of National Salvation « in the immediate aftermath of Numayri's ousting, shelved the Shari' $a$ issue out of deep concern for the consolidating of its power and the calming of the country's politics.

Indeed, the freeze of the Shari'a issue was central in Dahab's success to largely stabilize the political scene and hold the promised elections campaign in spring 1986. This was subsequented by the formation of a new government under Prime Minister Sadiq al-Mahdi, the leader of the Umma Party. The Democratic Unionist Party, another traditionally important politico-religious force in Sudan won the second place and joined Mahdi's government. Turabi's militant National Islamic Front (NIF) - a fresh split from the Muslim Brothers, emerged as the third significant force in Khartoum's politics, joining Mahdi's coalition government.

It was not long before the euphoria over the return of the state to political democracy - the first in eighteen years - began to dissipate, mainly as a result of the rekindling of fierce dispute over the role of the Shari' $a$ in the Sudanese society, hitting now not only north-south relations but also the very core of the north's politics. While Turabi's NIF spearheaded a vigorous campaign to revive the practical validity of the shelved Shari' a law, premier Mahdi acted to promulgate new legislation to replace it, positively responding thereby to one of the south's major prerequisites for opening a political negotiation toward conflict resolution. Aware of the fragile position of his government, however, Mahdi wished to avoid a political clash with Turabi's Islamists, which might have lead to the breakdown of his government and even more serious - to the collapse of the newly-born democratic system. The stormy northern-based dissension, which manifested itself also in a series of controversial agreements, signed in 1986 and 1988 between the southern SPLA and the northern political and professional elite - the National Forces for the National Salvation of Sudan, paralyzed Mahdi's government. ${ }^{28}$

Meanwhile, as the civil war escalated further and the regime's political prestige lost height, Turabi's NIF appreared more determined to fight for »Jihad [holy war]

and South Asia, Monitoring reports published by the US). For more details on the SPLA aims, see Mansour Khalid, John Garang Speaks, London and New York: KPI Ltd., 1987.

28 See Yehudit Ronen, "Sudan" in Middle East Contemporary Survey 1986, [and] 1988, Boulder, Co.: Westview Press, Vols. X and XII, pp. 584-85 and pp. 715-16, respectively. One of the main points in the 1986 Koka Dam agreement (after the name of the Ethiopian town where it was signed), was the repeal of the Shari' 1983 law. The 1988 agreement was in effect a repetition of the Koka Dam one. 
... until the government's fall or until it changes its decisions to obstruct the Shari ${ }^{6} .{ }^{29}$ Mahdi's government was obviously sitting on a volcano that was on the verge of erupting.

The lava eventually burst on June $30^{\text {th }} 1989$. The ultra-hard-liner Turabi, fed up with the stalemated Shari ${ }^{6}$ law, jointly acted with Islamist circles in the army and overthrew Mahdi's government in a successful coup d'etate. ${ }^{30}$ Top-echelon military officer Brigadier 'Umar Hasan Ahmad al-Bashir became the new head of state, while Turabi preferred to stay behind the scenes, hiding the Islamist character of the regime. On New Year's Eve of 1991, however, after consolidating its power base and with its self-confidence enhanced, the Turabi-Bashir Islamist regime officially announced the re-implementation of Shari'a law throughout the country »in compliance with Allah's clear ordinance excluding the south, at least »in the meantime ${ }^{31}$ Sudan was now turned into a fully Islamic state.

The southern leadership, while growingly beset by ideological, political, ethnic and personal schisms, considered the re-implementation of the Shari'a as a fatal obstacle to any dialogue. The political structure of the state should have been based on »secularism and equality of all people before the law « and not on religious law, protested Garang's SPLA, adding that with the re-implementation of the Shari'a, the desperate south sseriously consider " self-determination or even secession. ${ }^{32}$ The SPLA further clarified in a later occasion that the issue on the agenda was »not only Shari'a penalties but the entire NIF program of Islamicizing education, the mass media and social life in the whole country. «33

The south's separatist threat was flatly rejected by Bashir's government, stressing its total commitment to »the unity of Sudan's soil [which] cannot be an object of bargaining, trade or bartering $\ll{ }^{34}$ Bashir stressed at the same breath that »there is no God but Allah, « ${ }^{35}$ thus echoing again his perception of having the right to shape the state's national identity in the image of the Arab-Muslim heritage.

In the mid-1990s, the sharp Shari'a confrontation, although still maintaining its prominent place on the conflict's agenda, was increasingly surmounted by the two sides tough struggle for the oil resources and by the south's demands for self determination or secession. Moreover, loud voices in the divided southern leadership even held up the 1991 Eritrean model of independence, which was the culmination of almost three-decades of war against the Ethiopian governments, as an optional formula for settling the conflict. ${ }^{36}$

29 Al-Fatih 'Abdun, a central NIF figure, and Turabi quoted in al-Sharq al Awsat, London, May $4^{\text {th }}$ and $9^{\text {th }} 1989$, respectively.

30 For more details on the relations between the NIF and the armed forces, see Taha Haydar, al-Ikbwan wal-'Askar: Qissat al-Jabha al-Islamiyya wal-sulta fi al-Sudan, alQahira: Markaz al-Hadara al-'Arabiyya lil'Ilam wal-Nashr, 1993.

31 Al-Inqadh al-Watani, Khartoum, 5 January 1991.

32 Sudan Democratic Gazette, London, a southern publication, July 1992.

33 Sudan Democratic Gazette, July 1993.

34 Al-Inqadh al-Watani, January $15^{\text {th }} 1993$, quoting Bashir.

35 R. Omdurman (Khartoum), January $18^{\text {th }} 1995$ (DR).

36 Al-Wastat, London, August 30th 1993, quoting Rick Mashar, the leader of the splinter southern group SPLA-United. For details on the internal rivalries within the top 
Throughout the second half of the 1990s, coinciding with sporadic and definitely barren »peace talks, « the war heavily exacerbted, deteriorating in every respect to the north detriment, while also demanding tragic human and other terrible prices from the south. At that period, the war has considerably expanded from its internal context, facing growing political and military involvement of regional and international forces. Most alarming for the north, the south enjoyed the political and military support of a US-supported front, which included Uganda, Ethiopia and Eritrea, all of them strongly antagonistic to Bashir's Islamist regime.

Moreover, it was during this period that the intrastate map of the conflict was dramatically changed, again to the regime's detriment. Most significant was the unprecedented collaboration between the southern SPLA and various Muslim opposition parties from Khartoum's political core, as well as other non-southern forces, either from the Nuba Mountains, the Kassala region in eastern Sudan and other regimes, organizing themselves in an umbrella grouping - the National Democratic Alliance (NDA). ${ }^{37}$

Clearly, this comprehensive alliance of non-Muslim and Muslim forces indicated that the controversy over the Shari $a$ law was shifted from the center of the conflict's agenda and that Islam stopped to be a cementing common denominator for the diverse northern majority population, whereas opposition to further Islamization of the state stopped to be a primary rallying point for the extremely heterogeneous non-Muslim southern minority. Rather, the new NDA grouping, notwithstanding the different religious affiliations of its members, joined forces in what appeared at that stage as their first priority goal to overthrow the Turabi-Bashir regime and establish a new political order instead. Within this context, the NDA even targeted the Sudanese oil industry in 1999, thus imperiling the focal element of the politico-economic agenda of the regime, and undermining the state's economic prospects.

Notwithstanding with the escalating battles and the deteriorating political position of the government both internally and externally, Bashir and Turabi remained captive in their Islamist vision and hegemonic leadership perception, not compromising on any of the thorny issues on the conflict agenda. Most noteworthy among them were Sudan's territorial integrity, the role of the Shari'a in the state's life, and the sharing of oil resources, with the latter particularly assuming a much heavier weight in the conflict in late 1990s. Encouraged by its military success, the south appeared tough alike. Not surprising, therefore, the new rounds of sporadic talks, held in response to foreign pressures, remained entirely futile.

Meanwhile, in 1999, the genie of fierce power struggle between the two powerful leaders, Turabi and Bashir, had been let out of the bottle. By the end of the year, Bashir emerged triumphant, as Turabi was removed from power. »We have reached

southern leadership, see Yehudit Ronen, "Sudan « in Middle East Contemporary Survey 1992-1994, pp, 707-8, 619-20 and 597-98

37 The northern pillar of the NDA was composed of the Umma Party (the political organ of the Ansar sect), the Democratic Unionist Party, which derived a major support mainly from the Khatmiyya sect, the Communists, the trade and professional unions and others, encompassing thereby a dominant part of the northern religious and political fabric. 
the end of the road, ${ }^{38}$ Bashir stated, triggering hopes in Sudan and abroad of puncturing first and foremost the Islamist balloon and thus quickening the state's progress toward the redefinition of its religious and cultural identity and toward the redistribution of its political and economic sources. Yet, still needing the political support of Turabi's camp and wishing to avoid any further tremor, while believing in the pivotal role of Shari'a in the country's life, Bashir did not take, nor declare, any demonstrative move of loosing the Shari'a's formal status in the wake of Turabi's removal from power.

Yet, in effect, the impact of the Shari' $a$ in the Sudanese life seemed to abate in the early 2000s. Turabi - the ideological and major architect of Sudan's Islamism - has mostly been staying in prison or house arrest, while Egypt, the Gulf states, the neighboring African states and the US, each due to its own interests, exerted strong pressures upon Bashir to lower his state's Islamist profile. Bashir, even if for the sake of his hold on power, was aware of the political expediency inherent in dimming Sudan's Islamist »trade mark «.

In any case, the Shari'a issue was not the major bone of contention on the northsouth agenda during the post-Turabi period. Moreover, the somewhat odd agreement signed in mid-2001 between the Islamist Turabi and the non-Muslim southern SPLA - hitherto two most sworn enemies with strictly opposing positions towards the effect of the Shari'a law in the state's life and another cluster of substantial issues, indicated that when tactically required, the Shari' $a$ issue had been pushed to the margins, even by Sudan's most Islamist protagonist. While the SPLA and Turabi's NIF committed themselves to escalate "popular resistance « to Bashir's government, the word Shari $a$ did not appear in their agreement, though it vaguely referred to the need to respect Sudan's religious diversity. ${ }^{39}$ This indicated, once again, that the Shari' a division served mainly to fuel the conflict, being merely one of its sources, and definitely not the major one, although steadily being in the limelights of public attention.

Meanwhile, tragically for the whole of Sudan, the beginning of the $21^{\text {st }}$ century witnessed ongoing heavy fighting not only in the chronic south-north war, but also increasingly since early 2003, in the war in the Muslim but non-Arab western Darfur region, bordering Chad, thus adding a new potential component to the already complex intra- and inter-state war. A group calling itself the Sudan Liberation Movement or Army (SLM/A), in a clear and presumably deliberate resemblance to the name of the southern SPLM/A army, took up arms against Khartoum's government, demanding that it would put an end to Darfur's chronic political marginalization, racial discrimination, economic deprivation and backwardness. The Darfur re-

38 R. Omdurman, December $12^{\text {th }}$ - British Broadcasting Corporation, London (BBC), December $14^{\text {th }} 1999$. For more details, see Yehudit Ronen, "The Struggle for Power within Sudan’s Top Leadership, « Policy Watch 432 (1999); idem, »Sudan«, Middle East Contemporary Survey, Colorado: Westview Press 1999, pp. 529-31; J. Millard Burr and Robert O. Collins, Revolutionary Sudan: Hasan al-Turabi and the Islamist State, Leiden, The Netherlands: Brill, 2003, pp. 265-74.

39 For more details on this short-lived episode, see Country Report: Sudan, No. 2, June 2001, p. 13. 
bellious SLA, joined by another rebel group, the Justice and Equality Movement, further demanded that the Arab-Muslim elite in Khartoum halt the unceasingly raids of the Darfurian nomadic Arab Muslim Baqqara militias - known better as the Janjaweed - on the Darfurian Muslim farmers of Black African origin. Thus, the war in Darfur was also tinged with strong ethnic colors, affecting, even if not directly, the north-south conflict.

Yet, while causing a horrible toll of civilian casualties and human atrocities, as well as a frightful humanitarian crisis to the point of being even portrayed by various foreign media sources and US and UN officials as genocide, the Darfur war has nothing to do with differing religious faiths; rather, the Darfur war serves as an explicit illustration for the state's multitudinously-interwoven intricacies and polarizations in many respects with no connection at all in the interfaith tension, ${ }^{40}$ nor to the north-south conflict.

\section{Religion at War Time, yet Lightened Up by Peace Initiatives: 2002-2004}

Spurred by their own interests, as well as by strongly assertive foreign brokery with the US as the major driving force, the south and north held a series of interim "peace talks «, which eventually produced the Machakos agreement in July 2002 and the Naivasha agreement in September 2003 (both after the Kenyan towns where they were signed). The bottom line of these accords was the decision in principle on holding internationally-monitored referendum after a six-year interim period on self-determination for the people of the south, giving them the option to decide whether to remain part of a unified Sudan, as Khartoum's government so wished, or to secede. During the six-year interim period, the agreements stipulated, the south, while enjoying a considerable autonomy, will be exempted from the effect of the Shari a law.

Notwithstanding the tremendous progress in the negotiation, still a cluster of pivotal issues remained unsettled in late 2003, among them the effect of the Shari $a$ in Khartoum - the state's capital and a stronghold of the northern Muslim society and also a mega-city where millions of southerners live; the power- and wealth-sharing; the inclusion of key northern Sudanese parties (members of the NDA) to the negotiating table and the status of other disputed areas, i.e. the Abyei oil-rich region and the Nuba mountains, both in the Kordofan area, and the Ingassena region in the southern Blue Nile region. The south viewed these regions as part and parcel of its territory, basing its claim on geographically-ethnic succession and on the definition of these regions during the end of the colonial era as southern ones. Another stumbling block was the exclusion of regional players from the agreements, as the major

40 For more on the war in Darfur, see »Darfur Destroyed: Ethnic Cleansing by Government and Militia forces in Western Sudan, « Human Rights Watch, May 2004, Vol. 16, No. 6 (A); Robert O. Collins, "Disaster in Darfur, Geopolitique Africaine (forthcoming) and Yehudit Ronen, "The Tragedy in Darfur: Who is Going to Stop it? «Tel Aviv Notes, Mark Heller ed., Tel Aviv University, 1 August 2004. 
mediation player was the US and not the IGAD players, ${ }^{41}$ or Egypt and Libya, which had been intensively involved in earlier mediation efforts.

Nevertheless, both of the warring sides did not sit idly by. On May $26^{\text {th }} 2004$, while the Darfur warfare steadily escalated, a new breakthrough marked the northsouth conflict, manifesting itself in the signing, again in Naivasha, of another, complementary set of »peace accords «. These provided with compromises to some of the hitherto hard nuts issues to crack, primarily the power-sharing one. In addition, the agreements presented a compromise over the role of the Shari ${ }^{\prime} a$ in Khartoum, stipulating that Shari'a should continue to be implemented in the capital, whereas the non-Muslim southerners living there would not be affected by it. ${ }^{42}$ The agreements also provided with a compromise over solution to the above-mentioned disputed areas, anchoring their option to demand a special status in due time, ${ }^{43}$ and also incorporated the northern forces of the NDA to the negotiating table, holding talks in Jidda and Cairo in mid-2004.

The 2004 »peace agreements « indicated a tangible progress on the road to conflict resolution, or at least to conflict management, although the war was far from its end. It seemed nevertheless that both of the warring sides, each due to its own good reasons, has yearned for the termination of the civil war, the second longest in Africa after the war in Angola. This was plainly illustrated for example by Garang's southern SPLA, who declared in June 2004: "we have reached the crest of the last hill in our tortuous ascent to the height of peace [and] there are no more hills ahead of us. « ${ }^{44}$ With Garang's statement in mind, one should add his own prayer and say "Inshallah «, whether he is a Christian from the south or a Muslim from the north. ${ }^{45}$

Unfortunately, this conflict was still far from its resolution in summer 2004 and whenever it will be achieved, and whatever prices it will require, still the danger of the war's recurrence will be heavily looming on the state. Not only had Sudan itself shown this danger in 1983 but also this danger of crumbling peace agreements was further indicated by other wars in Africa, most prominent in Angola, Rwanda, Liberia and Congo during the 1990s-early 2000 s - all following the collapse of peace agreements.

41 IGAD, and in its full name the Inter-Governmental Authority on Development is an east African regional security organization, consisting of Ethiopia, Eritrea, Kenya, Uganda, Djibouti and Somalia. For more details on the IGAD mediation during the 1990s-2000, see Mansour Khalid, War and Peace in Sudan: The Tale of Two Countries, London: Kegan Paul, 2003, pp. 369-401.

42 Al-Hayat, London, May $26^{\text {th }} 2004$.

43 For more details on the agreements, see al-Ahram Weekly, June $3^{\text {rd }}-9^{\text {th }} 2004$, and Country Report: Sudan, June 2004, pp. 12-16.

44 Al-Ahram Weekly, June $3^{\text {rd }} 9^{\text {th }} 2004$, quoted by Gamal Nkrumah.

45 For a profound discussion on the implementation of peace agreements and their failure, see Ending Civil Wars, Stephen John Sedman, Donald Rothchild, and Elizabeth M. Cousens, Boulder Co.: Lynne Rienner Publishers, 2002. 


\section{Conclusion}

»Conflict is an inevitable aspect of human interaction, an unavoidable concomitant of choices and decisions, "stated one of the most outstanding social scientists in conflict studies. ${ }^{46}$ Within that context of choices and decisions, the persistent determination of the ruling Muslim elite in the north to the Islamization of the religiously and ethnically diversified Sudanese society during most of the period reviewed in this study, significantly nourished the flames of the south-north war. Yet, one should note that this Islamization ardor did not ignite the war, nor served as its major source of nourishment. Therefore, the Sudanese armed conflict, notwithstanding the intractability of its causes, should not be considered as a religious conflict per se, but rather as a conflict, wherein fundamental religious sentiments have been deeply woven.

Both warring parties vigorously hoisted their different religious banners upfront, turning them to be a major symbol of their identity and in the case of the north elite - although not systematically encompassing all of it - also a symbol of the state's identity. This waving of religious flags, while certainly reflecting both sides deep religious commitment, helped the two parties leaderships to consolidate the cohesion of their heterogeneous and split societies and reinforce their motivation to fight for the sake of what they perceived as their essential interests, in any case largely beyond religious matters.

Thus, while Islam has definitely been the dominant religion in the country, the assumption that the whole Muslim society in the north so wished to turn Sudan into a fully Islamic state notwithstanding the south unequivocal rejection is unequivocally untrue. This was demonstratably indicated by the resolute objection of politico-religious circles from the core of north to Numayri's Shari'a implementation and by even more massive and active objection in the core of the north to the Bashir-Turabi »mafiocracy, « as it was depicted by a senior northern politician, who himself had crossed the lines and joined the southern SPLA ${ }^{47}$ Moreover, the carving of the NDA on its flag the principle of separating the church and mosque from the state, and religion from the Sudanese politics, served as another important refutation of the wrongly perceived monolithic religious approach of the Muslim north.

Yet, even so, the fierce religious confrontation, which always has assumed a much greater weight than its real substantial significance on the north-south relations, has yielded a particularly combustible effect. This in turn, exacerbated the conflict's ethnic militancy and fueled the south's aspirations for self-determination or even secession. This means that while conflicts are often represented as religious ones, it is the national aspects of these conflicts that are their basic cause. ${ }^{48}$ Religious aspects are merely exacerbating factors and the Sudanese north-south war has not been an exception.

46 Francis M. Deng, I. William Zartman, »Conflict Reduction: Prevention, Management, and Resolution, « Conflict Resolution in Africa, p. 299.

47 Mansour Khalid, War and Peace, p. 295.

48 See Jonathan Fox, »Are Religious Minorities More Militant than Other Ethnic Minorities?« Alternatives, Vol. 28, 2003, pp. 91-114, Idem, »Religion and State Failure: An Examination of the Extent and Magnitude of Religious Conflict from 1950 to 1996," 


\section{Summary}

This article focuses on Sudan's armed conflict, which has been waging between the majority Arab-Muslim society and the Christian and Animist African minority society, dragging the whole state into a stormy maelstrom of havoc. The study surveys this conflict's full continuum in the years 1955-2004, analyzing with a particular emphasis the role and impact of religion in shaping the conflict's course and effects during both times of war and of peace. More explicitly, the article examines to what extent this conflict has been religious in its character, or rather, whether religion was merely one of the factors, albeit a powerful one, in fueling the flames of war. While discussing this challenging topic, particularly as interfaith tensions have always been tightly and almost inseparably interwoven into the most intricate Sudanese fabric of life, the paper also sheds light on, and maps relevant pre-independence histories junctions, as well as central political, economic and foreign policy crossroads of $\mathrm{Su}$ dan during the era of independence.

\section{Zusammenfassung}

Dieser Aufsatz beschäftigt sich mit dem bewaffneten Konflikt im Sudan zwischen der arabisch muslimischen Mehrheitsgesellschaft und der Minderheit von christlichen und animistischen Afrikanern, der den ganzen Staat in einen Wirbelsturm der Verwüstung gerissen hat. Die Studie betrachtet den gesamten Zeitraum des Konflikts zwischen den Jahren 1955 und 2004 und analysiert dabei vor allem die Rolle und die Triefkraft der Religionen, inwieweit sie den Konflikt hervorgerufen und den Weg gewiesen haben und zwar sowohl während der Kriegs- als auch der Friedenszeiten. Genauer untersucht die Studie inwieweit der Konflikt überhaupt einen religiösen Charakter besitzt, bzw. inwieweit die Religion nur einer der Faktoren war, wenn auch ein mächtiger, der Öl in die Flammen des Krieges goss. Indem man dieses herausfordernde Thema diskutiert, zeigen sich besonders die religiösen Spannungen in die Lebenszusammenhänge des Sudans eng und davon untrennbar verwoben, so wirft diese Studie dadurch auch Licht auf die relevanten historischen Knotenpunkte vor der Unabhängigkeit als auch auf die politischen, ökonomischen wie außenpolitischen Entwicklungen des unabhängigen Sudans.

International Political Science Review, Vol. 25, No. 1, 2004, pp. 55-76. For more on the role of religion in conflict, see David Little, "Religious Militancy, « Managing Global Chaos: Sources of and Responses to International Conflict, Chester A. Crocker and Fen O. Hampson, eds., Washington D.C.: US Institute of Peace Press, 1996, pp. 79-91, and Andreas Hasenclever and Volker Rittberger, »Does Religion Make a Difference? Theoretical Approaches to the Impact of Faith on Political Conflict, «Millenium, Vol. 29, No. 3, 2000, pp. 641-74. 